University of Nebraska - Lincoln

DigitalCommons@University of Nebraska - Lincoln

Faculty Papers and Publications in Animal

Science

Animal Science Department

2006

\title{
Correlated Responses in Maternal Performance Following \\ Divergent Selection for Heat Loss in Mice
}

\author{
J. M. McDonald \\ University of Nebraska-Lincoln \\ Merlyn . K. Nielsen \\ University of Nebraska-Lincoln, mnielsen1@unl.edu
}

Follow this and additional works at: https://digitalcommons.unl.edu/animalscifacpub

Part of the Animal Sciences Commons

McDonald, J. M. and Nielsen, Merlyn . K., "Correlated Responses in Maternal Performance Following Divergent Selection for Heat Loss in Mice" (2006). Faculty Papers and Publications in Animal Science. 512.

https://digitalcommons.unl.edu/animalscifacpub/512

This Article is brought to you for free and open access by the Animal Science Department at DigitalCommons@University of Nebraska - Lincoln. It has been accepted for inclusion in Faculty Papers and Publications in Animal Science by an authorized administrator of DigitalCommons@University of Nebraska - Lincoln. 


\title{
Correlated responses in maternal performance following divergent selection for heat loss in mice ${ }^{1}$
}

\author{
J. M. McDonald and M. K. Nielsen ${ }^{2}$
}

Department of Animal Science, University of Nebraska, Lincoln 68583-0908

\begin{abstract}
Divergent selection in mice was applied in 3 independent replicates for high (maintenance high; $\mathrm{MH}$ ) and low (maintenance low; ML) heat loss for 16 generations. An unselected control (maintenance control; MC) was also maintained in all replicates. Selection ceased for 26 generations; heat-loss measurement and selection resumed at generation 42 . Lactation performance, dam weight, dam feed intake, and efficiency of production of pup weight were recorded or calculated for $\mathrm{MH}$ and $\mathrm{ML}$ dams in all 3 replicates at generation 46 or 47 with the objective of determining whether selection for heat loss has created correlated responses in maternal performance. One-half of the dams reared their own litters, and one-half reared cross-fostered (across lines) litters. Between 10 and 12 litters were used from each replicate-line-rearing class. Litter size was recorded, and litters were standardized to 8 pups within $24 \mathrm{~h}$ of birth. For cross fostering, $\mathrm{MH}$ litters were matched to ML litters born within $24 \mathrm{~h}$ of each other, and MH-ML litter pairs were cross-fostered at 3 $\mathrm{d}$ of age. A weigh-suckle-weigh protocol was used to obtain milk production estimates over a 2 -h suckling period at 6, 9, 12, and $15 \mathrm{~d}$. Dam (plus litter) feed intake
\end{abstract}

was also recorded at these times and was calculated as the disappearance of feed over 3-d intervals. Dams of the MH selection tended $(P<0.11)$ to have greater litter size than those of the ML selection; litter size of MC dams was intermediate. Line of dam affected milk production $(P=0.04)$ and dam feed intake $(P<0.03)$ as MH dams produced more milk and consumed more feed than ML dams. Average milk production for the 2-h measurement period was $1.70 \pm 0.07$ and $1.41 \pm 0.07$ $\mathrm{g}$, and average 3 -d feed consumption was $50.8 \pm 1.2$ and $45.2 \pm 1.2 \mathrm{~g}$ for $\mathrm{MH}$ and ML dams, respectively. Crossfostering had no effect $(P>0.86)$ on milk production. Line of dam tended to affect 21-d litter weight $(P=$ $0.15)$ with litters reared by $\mathrm{MH}$ dams weighing more than those reared by ML dams, but there was no difference $(P>0.86)$ in 21 -d dam weights. Efficiency of producing litter weight (litter 15-d weight: dam plus litter feed intake from d 6 to 15$)$ was greater $(0.49$ vs. 0.46 , $\mathrm{SE}=0.009 ; P=0.03$ ) for ML than for MH dams. Selection for reduced heat loss (lower maintenance feed intake in the ML line) resulted in reduced milk production and feed intake in dams and greater efficiency of litter weight production.

Key words: feed intake, heat loss, maternal performance, mouse, selection

(C2006 American Society of Animal Science. All rights reserved.

J. Anim. Sci. 2006. 84:300-304

\section{INTRODUCTION}

The greatest economic inputs in livestock production are the costs associated with feeding animals; the cost of meeting the animal's maintenance requirements is the largest. Also, costs of maintenance per unit of body size are more variable than the costs above maintenance for feed per unit of production (i.e., milk production, growth, etc.). As food is metabolized in an animal, energy not stored in a product is lost in the form of

\footnotetext{
${ }^{1}$ A contribution of the Univ. of Nebraska Agric. Res. Division, Lincoln, NE. Journal Series No. 14599. This research was supported in part by funds provided through the Hatch Act.

${ }^{2}$ Corresponding author: mnielsen1@unl.edu

Received July 15, 2005.

Accepted September 6, 2005.
}

heat. The ability to measure maintenance requirements in the form of a proxy, heat production, and the existence of variation in heat loss make it possible to select animals based on their heat production/loss as a method to produce more efficient animals (Nielsen et al., 1997a,b). Nielsen et al. (1997a,b) found that selection for heat loss was effective, that the maintenance high (MH) and maintenance low (ML) lines diverged significantly, and that selection for low heat loss in the ML line was a successful way to reduce maintenance feed costs in mice.

Most of the previous research with these unique heatloss selection lines focused mainly on direct and correlated responses in males. Therefore, in this study we evaluated the effects of selection for heat loss on lactation performance and maternal feed intake in the $\mathrm{MH}$ and ML lines of mice. The objectives were to determine 
Table 1. Timeline for the weigh-suckle-weigh protocol

\begin{tabular}{lll}
\hline \hline & & Pup age \\
\cline { 2 - 3 } Time, h & \multicolumn{1}{c}{6 and $9 \mathrm{~d}$} & \multicolumn{1}{c}{12 and $15 \mathrm{~d}$} \\
\hline 0800 & Separate from dams $(1 \mathrm{~h})$ & Separate from dams $(1 \mathrm{~h})$ \\
0900 & Suckle-emptying period $(2 \mathrm{~h})$ & Suckle-emptying period $(2 \mathrm{~h})$ \\
1000 & & Separate from dams $(4 \mathrm{~h})$ \\
1100 & Separate from dams $(3 \mathrm{~h})$ & Weigh litter at separation \\
1200 & Weigh litter at separation & \\
1300 & & \\
1400 & & \\
1500 & & Suckle $(2 \mathrm{~h})$ \\
1600 & Suckle $(2 \mathrm{~h})$ & Weigh litter \\
\hline
\end{tabular}

if divergent selection for heat loss, as a proxy for energy requirements for maintenance, changed the dam's lactation performance and feed intake and, hence, efficiency of production.

\section{MATERIALS AND METHODS}

\section{Experimental Animals}

Lines of mice used for this study were described by Nielsen et al. (1997b) and represent the outcomes following divergent selection for heat loss. There were 3 criteria for selection: $\mathrm{MH}$ = selection for high heat loss, $\mathrm{ML}=$ selection for low heat loss, and maintenance control $(\mathbf{M C})=$ unselected control. Selection (original and renewed) was carried out in 3 replicates, each separated by a 5 -wk interval. Three replicates each with the 3 selection lines yielded 9 unique lines with an overall generation interval of $15 \mathrm{wk}$. Breeder males for each new generation were chosen from the previous generation's 16 litters in a line-replicate based on a single heat-loss measurement. Breeder females were randomly chosen from all 16 litters. After initial selection for 16 generations, selection ceased and the lines were maintained through generation 41 . The same sex-limited measurement of heat loss and selection process resumed within the heat-loss lines at generation 42 .

\section{Cross-Fostered and Naturally Reared Litters}

A cross-fostering study using only $\mathrm{MH}$ and ML females was conducted when dams from generation 46 , replicates 2 and 3 , and generation 47 , replicate 1 , were nursing their first litters. Divergent selection continued, except that 10 to 12 extra litters per line-replicate were produced and used for cross-fostering. Cross-fostering was used to separate effects of line of dam from line of pup. A similar number of dams reared their own litters, and these were the litters that represented the next generation in the selection process. Within $24 \mathrm{~h}$ of birth, all litters were sexed and total litter size was recorded. Litters were then standardized to 8 pups per litter, and only those litters with 7 or 8 live pups were used. Cross-fostering was accomplished by matching
MH-ML pairs of extra litters that were born within 24 $\mathrm{h}$ of each other. When the pups reached $3 \mathrm{~d}$ of age, they were cross-fostered with the corresponding dam from the opposite line.

\section{Weigh-Suckle-Weigh}

The design of this study was based on a milk-yield estimation study performed in rats (Morag, 1970). To measure milk production, a weigh-suckle-weigh protocol consisting of a series of separation and suckle periods was initiated at $6 \mathrm{~d}$ of age and repeated at 9, 12, and $15 \mathrm{~d}$ of lactation. Milk production was measured in dams with both cross-fostered and naturally reared litters. The weigh-suckle-weigh timeline is given in Table 1 .

The first separation period lasted $1 \mathrm{~h}$ and ensured that the pups did not have the opportunity to suckle. During this time, pups were taken from the dam's cage and placed in a separate clean cage. Litters that were 6 - and 9-d-old were given a supplemental heat source to keep them warm. Next, pups were returned to the dam's cage for a 2-h "emptying" suckle period. This period was designed to lower the CV in milk yield and, in theory, start the milk yield measurements when the mammary glands of every dam were nearly empty. Once the 2-h suckle period was completed, pups were again separated from the dams for 3 or $4 \mathrm{~h}$ depending on their age. This separation allowed for milk production to occur in the dams and for the pups to become hungry. Total litter weight was measured and recorded at the time of separation. Then, the pups were placed back into the cages with the dams and allowed to suckle for $2 \mathrm{~h}$. At the end of the 2-h suckle period, entire litter weights were recorded. Milk production was calculated as the difference between the final and initial litter weights.

\section{Maternal Feed Intake}

Lactating dams were given ad libitum access to water and a high-energy lactation diet (Teklad 8626: 20\% CP, $10 \%$ crude fat, $2 \%$ crude fiber, and $3.8 \mathrm{kcal} / \mathrm{g}$ of ME; Harlan Teklad, Madison, WI). Dam feed intake was 
measured on the same day as the weigh-suckle-weigh protocol. Maternal feed intake was calculated as the amount of feed disappearance from the hanging basket since the last weighing ( $3 \mathrm{~d}$ earlier). Weighted plexiglass covers over feed baskets were used to ensure that no feed was spilled or lost. As pups matured and started eating solid food, measurement of feed intake included the feed eaten by dams and the small amount consumed by pups.

\section{Weaning}

Cross-fostered and naturally reared litters were weaned at $21 \mathrm{~d}$ of age. At weaning, dam and total litter weights were recorded. Naturally reared litters were those being produced to provide heat-loss measurements for selection purposes. Males and females from these litters were separated and housed in full-sibling cages. Cross-fostered litters were not needed to continue the selection in the heat-loss lines and therefore were killed by carbon dioxide asphyxiation. This research was carried out under University of NebraskaLincoln IACUC protocol \#04-05-025.

\section{Statistical Analysis}

All analyses were done using the Mixed procedure of SAS (SAS Inst., Inc., Cary, NC); correct df were obtained using the Satterthwaite option.

Litter size data were described by the model

$$
\begin{gathered}
\mathrm{Y}_{\mathrm{ijkl}}=\text { rep }_{\mathrm{i}}+\text { line }_{\mathrm{j}}+\text { generation }_{\mathrm{k}}+\left(\text { rep }^{*} \text { line }\right)_{\mathrm{ij}} \\
+\left(\text { rep*generation }_{\mathrm{ik}}+\left(\text { line }^{*} \text { generation }_{\mathrm{jk}}\right.\right. \\
+\left(\text { rep*line* generation }_{\mathrm{ijk}}+\text { error }_{\mathrm{ijkl}},\right.
\end{gathered}
$$

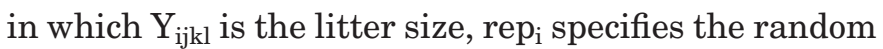
effect of the replicate (replicate 1,2 , or 3 ), line $e_{j}$ is the fixed effect of the line (MH, ML, or MC), generation ${ }_{\mathrm{k}}$ is the fixed effect of the generation (generation 42 through 46), (line*generation) ${ }_{\mathrm{jk}}$ is the fixed interaction of line and generation, and the remaining terms are random effects to complete the model. Orthogonal contrasts of $\mathrm{MH}$ vs. $\mathrm{ML}$ and $[\mathrm{MH}+\mathrm{ML}] / 2$ vs. $\mathrm{MC}$ were carried out to test the effect of selection and asymmetry of selection.

Milk yield and maternal (dam + litter) feed intake data were described by the model

$$
\begin{aligned}
& \mathrm{Y}_{\mathrm{ijklm}}=\operatorname{rep}_{\mathrm{i}}+\operatorname{line}_{\mathrm{j}}+\text { rear }_{\mathrm{k}}+\left(\text { rep*line }_{\mathrm{ij}}+\left(\text { rep*rear }_{\mathrm{ik}}\right.\right. \\
& +\left(\text { line }^{*} \text { rear }\right)_{\mathrm{jk}}+(\text { rep*line*rear })_{\mathrm{ijk}} \\
& + \text { dam }\left(\text { rep*line*rear }_{i \mathrm{ijk}}+\text { stage }_{\mathrm{m}}+\left(\text { stage }^{*} \text { line }\right)_{\mathrm{jm}}\right. \\
& +(\text { stage*rear })_{\mathrm{km}}+(\text { stage*line*rear })_{\mathrm{jkm}}+\mathrm{e}_{\mathrm{ijklm}} \text {, }
\end{aligned}
$$

in which $\mathrm{Y}_{\mathrm{ijklm}}$ is milk yield or maternal feed intake; $\mathrm{rep}_{\mathrm{i}}$ specifies a random replicate effect (replicate 1, 2, or 3); line $e_{j}$ is the fixed effect of the line (MH or ML) of dam; rear $_{\mathrm{k}}$ is the fixed effect of cross-fostering status; (line*rear) $)_{\mathrm{jk}}$ is the fixed interaction of line and crossfostering status, which is confounded with and was in-
Table 2. Litter size at first parity averaged across 3 replicates during each of 4 generations of selection ${ }^{1}$

\begin{tabular}{lccc}
\hline \hline & \multicolumn{3}{c}{ Line $^{2}$} \\
\cline { 2 - 4 } Generation & MH & MC & ML \\
\hline 42 & $11.51 \pm 0.62$ & $11.91 \pm 0.61$ & $10.26 \pm 0.61$ \\
43 & $12.39 \pm 0.61$ & $11.35 \pm 0.61$ & $11.32 \pm 0.61$ \\
44 & $11.66 \pm 0.62$ & $11.66 \pm 0.61$ & $10.85 \pm 0.62$ \\
45 & $11.80 \pm 0.61$ & $11.53 \pm 0.61$ & $10.29 \pm 0.61$ \\
46 & $12.01 \pm 0.61$ & $11.52 \pm 0.62$ & $10.14 \pm 0.61$ \\
Average $^{3}$ & $11.88 \pm 0.51$ & $11.60 \pm 0.50$ & $10.57 \pm 0.50$ \\
\hline
\end{tabular}

${ }^{1}$ Means $\pm \mathrm{SE}$.

${ }^{2} \mathrm{MH}=$ high heat-loss selection, $\mathrm{ML}=$ low heat-loss selection, and $\mathrm{MC}=$ unselected control. Number of observations for line-generation classes ranged from 87 to 104 .

${ }^{3}$ Effect of selection, MH vs. ML, $P<0.11$. Asymmetry of selection, $[(\mathrm{MH}+\mathrm{ML}) / 2]$ vs. $\mathrm{MC}, P=0.54$.

terpreted as any effect of line of pups; dam(rep*line* rear $)_{\mathrm{ijkl}}$ is the random effect of an individual dam; sta$\mathrm{ge}_{\mathrm{m}}(6,9,12$, or $15 \mathrm{~d}$ when analyzing milk-yield data, or 6 to 9,9 to 12 , or 12 to $15 d$ when analyzing maternal feed intake data) specifies the fixed effect of the stage of lactation within a dam. The other interactions are self-evident. The last term $\left(\mathrm{e}_{\mathrm{ijklmn}}\right)$ is the random effect for testing stage and the interactions of fixed effects with stage.

Efficiency of producing pup weight was calculated as the weight of the entire litter at $15 \mathrm{~d}$ divided by the total maternal feed intake through $15 \mathrm{~d}$ of lactation. These efficiency estimates, as well as dam weight at 21 $\mathrm{d}$ and litter weight at $21 \mathrm{~d}$, were fitted to the model

$$
\begin{aligned}
\mathrm{Y}_{\mathrm{ijk}} & =\text { rep }_{\mathrm{i}}+\text { line }_{\mathrm{j}}+\operatorname{rear}_{\mathrm{k}}+\left(\text { rep*line }_{\mathrm{ij}}+\left(\text { line }^{*} \text { rear }\right)_{\mathrm{jk}}\right. \\
& +\left(\text { rep*rear }_{\mathrm{ik}}+\left(\text { rep*line*rear }_{\mathrm{ijk}}+\text { error }_{\mathrm{ijk}},\right.\right.
\end{aligned}
$$

in which $\mathrm{Y}_{\mathrm{ijk}}$ is the efficiency estimate, BW, or litter weight for a single dam; and $\mathrm{rep}_{\mathrm{i}}$, line $\mathrm{j}_{\mathrm{j}}$, and rear $_{\mathrm{k}}$ are as just defined.

\section{RESULTS AND DISCUSSION}

Litter size was measured as the total number of pups (dead and alive) at parturition. Litter sizes for each generation-line and across all 5 generations are presented in Table 2 . The test for selection response ( $\mathrm{MH}$ vs. ML) tended toward significance $(P<0.11)$, and there was no evidence for asymmetry of selection response $(P=0.54)$. These results are similar to those observed by Nielsen et al. (1997a), except that the difference between the MH and ML was greater and more significant after generation 15 than in the more recent generations used in the current study. As in the earlier report, $\mathrm{MH}$ dams produced more pups than ML dams, and MC dams were intermediate for litter size born. Nielsen et al. (1997a) demonstrated that differences in litter size among the lines were due to differences in ovulation rate. 
Table 3. Milk production per 2-h collection for $\mathrm{MH}$ and ML dams averaged across all 3 replicates ${ }^{1}$

\begin{tabular}{lll}
\hline \hline & \multicolumn{2}{c}{ Line $^{3}$} \\
\cline { 2 - 3 } Day $^{2}$ & MH dams, g & ML dams, g \\
\hline $6 \mathrm{~d}$ & $1.59 \pm 0.10$ & $1.20 \pm 0.10$ \\
$9 \mathrm{~d}$ & $1.72 \pm 0.10$ & $1.41 \pm 0.10$ \\
$12 \mathrm{~d}$ & $1.80 \pm 0.10$ & $1.52 \pm 0.10$ \\
$15 \mathrm{~d}$ & $1.70 \pm 0.10$ & $1.52 \pm 0.10$ \\
Average $^{4}$ & $1.70 \pm 0.07$ & $1.41 \pm 0.07$ \\
\hline
\end{tabular}

\footnotetext{
${ }^{1}$ Means $\pm \mathrm{SE}$.

${ }^{2}$ Day $=6,9,12,15 \mathrm{~d}$ of lactation, $P<0.01$.

${ }^{3} \mathrm{MH}=$ high heat-loss selection $(\mathrm{n}=66)$, and $\mathrm{ML}=$ low heat-loss selection $(\mathrm{n}=65)$.

${ }^{4} \mathrm{MH}$ vs. ML, $P<0.04$.
}

Estimates of milk production per collection period for $\mathrm{MH}$ and ML dams averaged across all 3 replicates are shown in Table 3. Cross-fostering had no effect on milk production $(P>0.86)$, but $\mathrm{MH}$ dams produced more milk than ML dams $(P<0.04)$. Realized averages across replicate and production period were 1.70 and $1.41 \pm$ $0.07 \mathrm{~g}$ in $2 \mathrm{~h}$ for $\mathrm{MH}$ and $\mathrm{ML}$, respectively. There was no effect of line of pup (line of dam $\times$ cross-fostering interaction, $P=0.97$ ) on milk production.

These results support the findings of Ferrell and Jenkins (1985) and Montao-Bermudez et al. (1990). In their research, variation in maintenance requirements of cattle was associated with the milk production potential of an animal. Therefore, animals with greater milking ability will generally have greater maintenance requirements when adjusted for size. In our case, mice selected for greater maintenance requirements have demonstrated greater milking ability and are the same size. Taylor et al. (1986) compared maintenance requirements of low and high milking breeds of cattle. They found that beef breeds had lower maintenance requirements than those of dual-purpose breeds.

As expected, day of lactation had an effect on milk production $(P<0.01)$. Day-of-lactation means for the 2 $\mathrm{h}$ measurement were $1.40,1.56,1.66$, and $1.61 \pm 0.07$ $\mathrm{g}$ for $\mathrm{d} 6,9,12$, and 15 , respectively. Peak lactation fell after the greatest observed production on d 12. Hanrahan and Eisen (1970) described a lactation curve for mice in which peak lactation was between 12 and 13 $\mathrm{d}$ after parturition. Speakman and McQueenie (1996) investigated energy demands during different reproductive phases and found that mice vary in the amount of milk produced throughout the lactation period. They reported that peak milk production occurs around d 14 of lactation.

Maternal feed intake was measured during d 6 to 15 of lactation. Feed intakes by line and period are presented in Table 4. Line of dam affected feed intake $(P<0.03)$; $\mathrm{MH}$ dams consumed more feed overall than ML dams. Production period also affected maternal feed intake $(P<0.001)$; consumption increased over the course of lactation and was $43.59,48.80$, and $51.59 \pm$ $1.05 \mathrm{~g}$ for d 6 to 9,9 to 12 , and 12 to 15 , respectively.
Table 4. Maternal feed intake per collection period for $\mathrm{MH}$ and ML dams averaged across all 3 replicates ${ }^{1}$

\begin{tabular}{lcc}
\hline \hline & \multicolumn{2}{c}{ Line of dam } \\
\cline { 2 - 3 } Day $^{2}$ & $\mathrm{MH}, \mathrm{g}$ & ML, g \\
\hline 6 to $9 \mathrm{~d}$ & $47.12 \pm 1.48$ & $40.06 \pm 1.49$ \\
9 to $12 \mathrm{~d}$ & $52.06 \pm 1.48$ & $45.55 \pm 1.49$ \\
12 to $15 \mathrm{~d}$ & $53.17 \pm 1.48$ & $50.01 \pm 1.49$ \\
Average $^{4}$ & $50.78 \pm 1.17$ & $45.21 \pm 1.18$
\end{tabular}

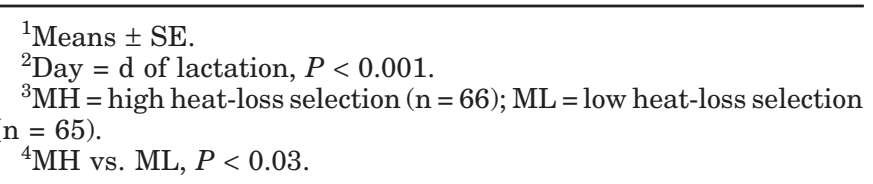

Neither cross-fostering $(P=0.42)$ nor line of pup (line of dam (cross-fostering interaction, $P=0.51$ ) affected maternal feed intake.

About $60 \%$ of the difference between $\mathrm{MH}$ and ML dams in maternal feed intake $(1.86 \mathrm{~g} / \mathrm{d}$ during the period of $d 6$ through 15) is explained by the energy required to support the difference in milk production. Based on work by Johnson et al. (2001), we expect that our 2-h collection of milk reflects about one-eighth, not one-twelfth, of daily milk production; thus we predict that the $\mathrm{MH}$ dams were producing about $2.32 \mathrm{~g}$ more milk/d than ML dams. Using assumed values of ME content of the feed $(3.8 \mathrm{kcal} / \mathrm{g})$, energy content (Johnson et al., 2001) of the dam's milk (2.87 kcal/g for ML and $2.64 \mathrm{kcal} / \mathrm{g}$ for $\mathrm{MH}$ in which energy content of milk is adjusted for weight of milk produced), and a partial efficiency of 0.8 for conversion of ME to retained energy in milk (Romero et al., 1976), then 1.16 of the $1.86 \mathrm{~g} / \mathrm{d}$ difference in feed intake is predicted to be due to milk production difference, and the remainder is presumed to be due to maintenance difference. After subtracting the predicted feed intake to meet average milk production of each of the 2 lines, ML dams have about $14 \%$ lower calculated maintenance cost for the same body size as $\mathrm{MH}$ dams.

Litter and dam 21-d weaning weights are given in Table 5. The effects of line of dam $(P=0.15)$ and line of pups (line of dam $\times$ cross-fostering interaction, $P=$ $0.19)$ approached significance for 21-d litter weights.

Table 5. Litter weight and dam weight at $21 \mathrm{~d}$ and dam efficiency (litter weight divided by dam feed intake) of producing litter weight to $15 \mathrm{~d}$ across all 3 replicates and rearing groups ${ }^{1}$

\begin{tabular}{lccc}
\hline \hline $\begin{array}{l}\text { Line of } \\
\text { dam }^{2}\end{array}$ & Litter weight, g & Dam weight, g & Efficiency, g/g \\
\hline $\mathrm{MH}$ & $105.62 \pm 5.35$ & $36.09 \pm 1.24$ & $0.460 \pm 0.009$ \\
$\mathrm{ML}$ & $95.54 \pm 5.36$ & $36.21 \pm 1.24$ & $0.487 \pm 0.009$ \\
$P$ & 0.15 & 0.86 & 0.03 \\
\hline
\end{tabular}

\footnotetext{
${ }^{1}$ Means \pm SE.

${ }^{2} \mathrm{MH}=$ high heat-loss selection $(\mathrm{n}=66) ; \mathrm{ML}=$ low heat-loss selection $(\mathrm{n}=65)$.
} 
Surprisingly, effect of line of pups appeared to be greater $(P=0.08)$ for $21-d$ dam weights than for pup weights. However, there were no effects of cross-fostering $(P=0.77)$ or line of dam $(P=0.86)$ on dam weights at $21 \mathrm{~d}$.

Efficiency means (weight of a litter at $15 \mathrm{~d}$ of age divided by the total feed intake of the dam between $d$ 6 and 15 of lactation) for MH and ML dams are also given in Table 5. The ML dams had greater efficiency than $\mathrm{MH}$ dams $(P=0.03)$. As noted previously, ML dams produced less milk and tended to have lighter litter weights than $\mathrm{MH}$ dams. Yet the lower maintenance costs of ML dams contributed to offsetting the lower litter weight output, resulting in the greater efficiency of the ML dams. Van Oijen et al. (1993) investigated biological and economical efficiencies in low, medium, and high milking crosses of beef breeds. Their findings also showed that cows with lower potential for milk production were more efficient even though producing less calf weaning weight.

Data on the MC line were collected and analyzed for litter size, but data were not collected on the MC line for milk production, dam or litter weights, dam feed intake, or efficiency. Thus, asymmetry of selection response could not be tested in these latter characteristics. We have made the assumption that the significant correlated responses (milk production, dam feed intake, and efficiency) were symmetric because other measures of significant correlated responses that we have studied and reported in which the MC line was included (feed intake of 8- to 11-wk males, body fatness, and locomotor activity; Nielsen et al., 1997a and Mousel et al., 2001) have all been symmetric. Our assumption is straightforward for dam feed intake and efficiency based on our other data in these lines of mice. Our assumption of a symmetric response in milk production agrees with historical evidence in cattle. Thus we have interpreted these significant correlated responses to have resulted from the divergent selection practiced in the $\mathrm{MH}$ and ML lines.

\section{IMPLICATIONS}

Selection for reduced heat loss per unit of metabolic size in the low heat loss line has produced mice that are more efficient at utilizing food. However, this selection has resulted in decreased maternal performance. Although low heat loss line dams are more efficient at producing pup weight in standardized litters, they have smaller litter sizes at birth and lighter pup weights at weaning because of less milk production. Based on these results with mice, beef cattle breeders who are interested in improving feed efficiency in cow herds should select animals with lower breeding values for maintenance requirements and milk production.

\section{LITERATURE CITED}

Ferrell, C. L., and T. G. Jenkins. 1985. Cow type and the nutritional environment: Nutritional aspects. J. Anim. Sci. 61:725-741.

Hanrahan, J. P., and E. J. Eisen. 1970. A lactation curve for mice. Lab. Anim. Care 20:101-104.

Johnson, M. S., S. C. Thomson, and J. R. Speakman. 2001. Limits to sustained energy intake. I. Lactation in the laboratory mouse Mus musculus. J. Exp. Biol. 204:1925-1935.

Montaño-Bermudez, M., M. K. Nielsen, and G. H. Deutscher. 1990. Energy requirements for maintenance of crossbred beef cattle with different genetic potential for milk. J. Anim. Sci. 68:2279-2288.

Mousel, M. R., W. W. Stroup, and M. K. Nielsen. 2001. Locomotor activity, core body temperature and circadian rhythms in mice selected for high or low heat loss. J. Anim. Sci. 79:861-868.

Morag, M. 1970. Estimation of milk yield in the rat. Lab. Anim. 4:259-272.

Nielsen, M. K., B. A. Freking, L. D. Jones, S. M. Nelson, T. L. Vordorstrasse, and B. A. Hussey. 1997a. Divergent selection for heat loss in mice: II. Correlated responses in feed intake, body mass, body composition, and number born through fifteen generations. J. Anim. Sci. 75:1469-1476.

Nielsen, M. K., L. D. Jones, B. A. Freking, and J. A. DeShazer. 1997b. Divergent selection for heat loss in mice: I. Selection applied and direct response through fifteen generations. J. Anim. Sci. 75:1461-1468.

Romero, J. J., R. Canas, R. L. Baldwin, and L. J. Koong. 1976. Lactational efficiency complex of rats: Provisional model for interpretation of energy balance data. J. Dairy Sci. 59:57-67.

Speakman, J. R., and J. McQueenie. 1996. Limits to sustained metabolic rate: The link between food intake, basal metabolic rate, and morphology in reproducing mice, Mus musculus. Physiol. Zool. 69:746-769.

Taylor, C. S., R. B. Theissen, and J. Murray. 1986. Interbreed relationship of maintenance efficiency to milk yield in cattle. Anim. Prod. 43:37-61.

Van Oijen, M., M. Montaño-Bermudez, and M. K. Nielsen. 1993. Economical and biological efficiencies of beef cattle differing in level of milk production. J. Anim. Sci. 71:44-50. 